\title{
Mening og relationer i flipped learning
}

\section{En undersøgelse af de studerendes oplevelse af et flipped lear- ning undervisningsforløb i videnskabsteori}

\author{
Dorte Toudal Viftrup, Forskningsenheden for Almen Praksis, Institut for Sundhedstjenesteforskning, \\ Syddansk Universitet \\ Niels Christian Hvidt, Forskningsenheden for Almen Praksis, Institut for Sundhedstjenesteforskning, \\ Syddansk Universitet
}

\begin{abstract}
Artiklen præsenterer en undersøgelse af. hvorvidt og hvordan de studerende oplevede et flipped learning undervisningsforløb i videnskabsteori som relevant, samt hvilke dele af undervisningen, de oplevede, understøttede deres læring.

Et mindre mixed methods design blev benyttet. 36 studerende besvarede et spørgeskema med både kvalitative og kvantitative items, og vi udførte fokusgruppeinterview med 4 studerende. En fortolkende fænomenologisk metode- og analysedesign blev benyttet. Fire temaer blev fremanalyseret på baggrund af det kvalitative data: 1. Mening, 2. Forberedelse og deltagelse, 3. Forventninger og 4. Relationer.

Undersøgelsen viste, at de studerende i høj grad oplevede flipped learning undervisningsmetoden som relevant og understøttende for deres læring, men at dette hang sammen med, at undervisningen blev gjort meningsfuldt for dem af underviser, og at de oplevede tryghed i relation til underviser, medstuderende og i læringskonteksten. Mening og relationer i læringssituationer var centralt for at de studerende blev aktive medskabere af egen læring og indgik i de relationelle læringsprocesser.
\end{abstract}

\section{Engelsk abstract}

The article presents a study on whether and how the students perceive a flipped learning course in history of science as relevant, and which parts of the teaching they experienced supported their learning.

A smaller mixed methods design was applied. 36 students answered a questionnaire with both qualitative and quantitative items, and we conducted focus group interview with 4 students. An interpretative phenomenological method and analysis design was used. Four themes were identified based on the qualitative data: 1. Meaning, 2. Preparation and participation, 3. Expectations and 4. Relationships.

The study found that the students greatly experienced the flipped learning teaching method as relevant and supportive of their learning, but this was due to the fact that the teaching was made meaningful to them by the teacher, and they felt secure in relation to the teacher, fellow students. and in the learning context. Meaning and relationships in learning situations were central to the students becoming active co-creators of their own learning and were included in the relational learning processes between students and the learning context. 


\section{Introduktion}

I denne artikel undersøges et flipped learning undervisningsforløb for faget videnskabsteori på 3. semester på bacheloruddannelsen i hhv. audiologi og audiologopædi på Syddansk Universitet. Hensigten er at undersøge, hvorvidt og hvordan de studerende oplever denne undervisningsmetode relevant, og hvilke dele af undervisningen, de oplever, understøtter deres læring.

Undersøgelsen var en del af et udviklingsprojekt på universitetspædagogikum ved Syddansk Universitet, som førsteforfatteren i 2019 deltog i. Førsteforfatter havde allerede undervist i faget videnskabsteori i 2 semestre på samme uddannelse. Slut-evalueringerne blandt de studerende efter hvert semester pegede på et begrænset læringsudbytte med den klassiske forelæsningsform. Et kritikpunkt der særligt blev rejst, var de studerendes oplevelse af, at undervisningen 'gik hen over hovedet på dem', og det resulterede i, at de ikke deltog aktivt i timerne. Et andet væsentligt kritikpunkt hang sammen med, at de studerende ikke forstod fagets relevans for deres fagfelter hhv. audiologi og audiologopædi. Med en bachelor i audiologi arbejder man med udredning og behandling af hørehandikap og tinnitus, mens en bachelor i audiologopædi er uddannelse som høre-, tale- og læsepædagog (audiologopæd). Audiologopædi-feltet beskæftiger sig med diagnostik, undervisning, behandling og forskning i forbindelse med læse-, stave-, skrive-, høre-, tale- og stemmevanskeligheder. Audiologi og audiologopædi er videnskabelige og forskningsbaserede uddannelser med et klart praksisnært sigte.

Vi valgte at afprøve flipped learning undervisningsmetoden med henblik på at øge de studerendes oplevede læringsudbytte af faget videnskabsteori.

\section{Baggrund}

Flipped learning handler om at vende undervisningen om, og derved skabe nye betingelser for de studerendes læringsproces. Den del af undervisningen som tidligere blev udført som forelæsning, hvor underviser formidler grundbegreber og forståelse om et givent emne, bliver i stedet lagt ud som pre-class forberedelse forud for en interaktiv in-class undervisning. De studerende forbereder sig ved hjælp af videoer, læsninger eller andre læringsaktiviteter, som underviser gør tilgængelige for dem. Når eleverne ankommer in-class, har de derved allerede grundlæggende viden, og tiden kan bruges til at skabe dybere forståelse og læring i samspil med medstuderende og underviser (Pierce \& Fox, 2012). I den klassiske forelæsningsform modtager de studerende grundviden og introduktion til begreber under forelæsningen, hvor underviser primært envejskommunikerer. Derefter skal de studerende på egen hånd eller i læsegrupper tilegne sig dybere forståelse for og brug af begreber og viden. Når de studerende med flipped learning metoden i stedet kommer forberedt til in-class, kan de udforske og arbejde dybere med emnet, end hvis de mødte det for første gang (O'Flaherty \& Phillips, 2015). Med flipped learning bliver klasseundervisningen et sted med højere ordens tænkning. I henhold til Blooms taksonomi er "huske" / "vide" det første og mest basale tænkningsniveau (Krathwohl, 2002), og når de studerende ankommer til in-class, og allerede har nået dette første niveau gennem pre-class forberedelsen, åbnes døren for at de kan deltage i højere ordenstænkning i in-class-aktiviteterne (Estes et al., 2014). Studier peger på, at de studerendes engagement i og ejerskab for undervisning er centralt for læring (Barkley, 2010; Bryson \& Hand, 2007), og flipped learning som undervisningsmetode fremmer de studerendes oplevelse af ejerskab for egen læring gennem det forberedende, forudgående pre-class arbejde, samt ved den interaktive undervisningsform i klasse-undervisningen (Hockings et al., 2008; Lage et al., 2000; O'Flaherty \& Phillips, 2015). Endvidere peger studier på, at flipped learning både fremmer de studerendes oplevelse af meningsfuldhed i undervisningen (Estes et al., 2014) og øger deres generelle læringsoplevelse (Mason et al., 2013; Wilson, 2013).

Historisk set har forskningsbaseret undervisning (FU) altid været kendetegnende for universiteterne, og idealet er, at de studerende skal lære ved at indgå i de videnskabelige processer (Dohn \& Dolin, 2015). 
Denne forskningsbasering af undervisningen er indskrevet i Universitetsloven af 2019 (paragraf 1, stk. 1). Universitetsuddannelsesforsker Mick Healey (2005) er optaget af forskellige måder forskning og undervisning kobles på. Han opstiller en model med to akser: 1. I hvor høj grad de studerende er deltagende versus blot tilhørere, og 2. Vægtningen af forskningsindhold versus forskningsprocesser og -problemer i undervisningen (Healey, 2005; Healey et al., 2010). Modellens fire kvadranter peger på forskellige tilgange, hvorved undervisnings - og læringsaktiviteter tilrettelægges i kobling mellem forskning og undervisning. Den første kvadrant omhandler forskningsledet undervisning, hvor de studerende primært er tilhørere, mens underviser forelæser over aktuelt forskningsindhold. Det kender vi som den klassiske forelæsning. Den anden kvadrant, hvor de studerende er tilhørere, men hvor der er fokus på forskningsprocesser og -problemer betegnes forskningsorienteret undervisning. For faget videnskabsteori kan dette være, at de studerende overværer en diskussion mellem to forskere, der repræsenterer to forskellige videnskabsteoretiske positioner. Når forskningsindhold vægtes, og de studerende er deltagende, beskrives undervisningen som forskningsstøttet. Det kan f.eks. være, når de studerende skal diskutere et videnskabsteoretisk emne. Den sidste kvadrant betegner Healey som forskningsbaseret undervisning, og her vægtes forskningsprocesser og problemer, ved at de studerende selv formulerer forskningsspørgsmål og undersøger dem med forskningsmetoder. Det kan for faget videnskabsteori gøres gennem mere problembaseret undervisning.

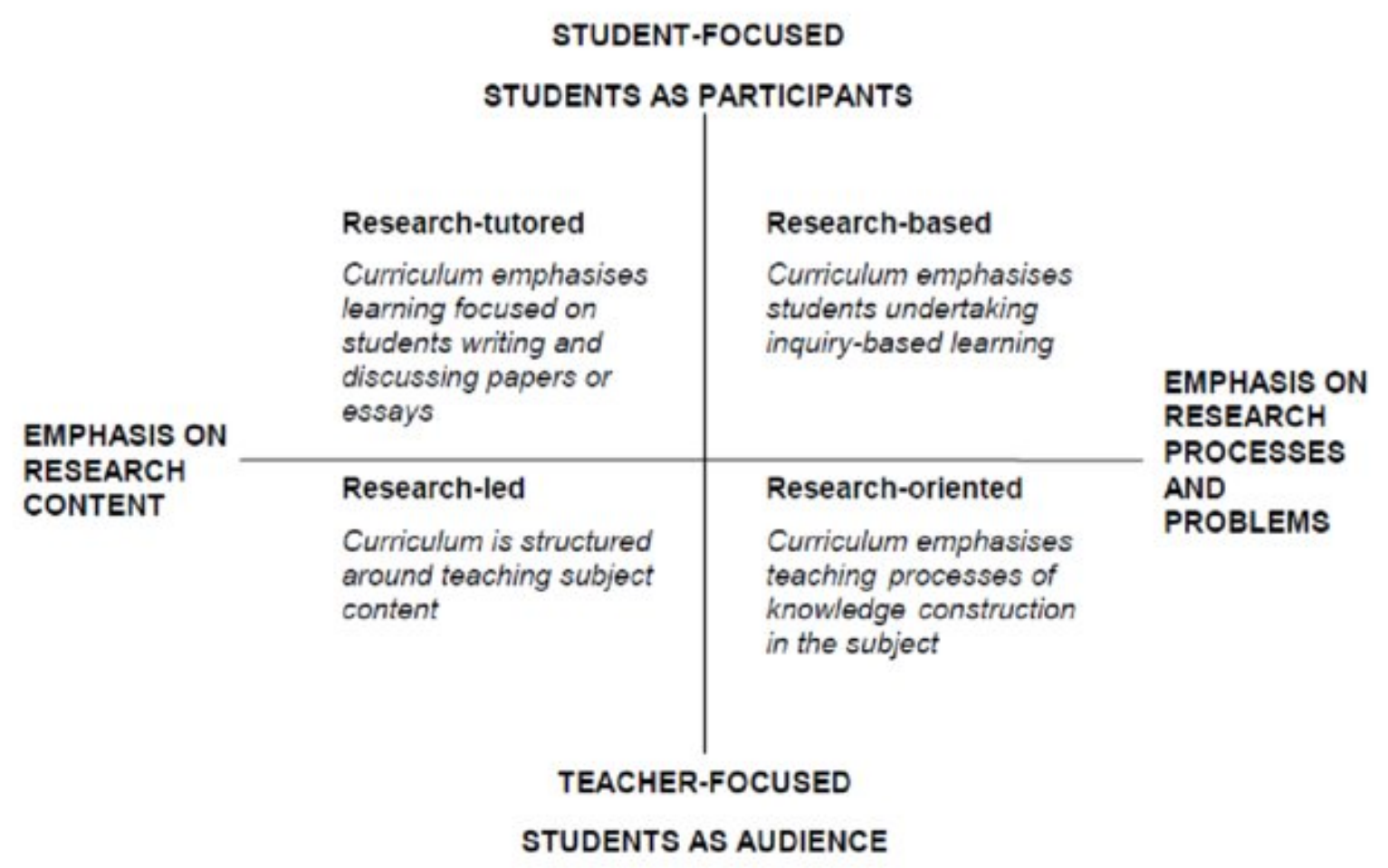

Figur 1. Healeys kvadrant (Obwegeser \& Papadopoulos, 2016)

Undervisning i videnskabsteori på bacheloruddannelsen for audiologi og audiologopædi har, indtil implementeringen af flipped learning metoden, overvejende været tilrettelagt som forskningsledet og støttet undervisning. Den har været struktureret omkring forelæsning samt refleksion og diskussion i små grupper og plenum. Vi oplevede dog, at kun en begrænset del af de studerende deltog i de forskningsstøttede aktiviteter. Evalueringerne pegede på, dette skyldtes, at de studerende manglede forståelse for faget og dets relevans for deres praksis-virkelighed. Med flipped learning metoden vendte vi om på vores brug af undervisning og læringsaktiviteter. Vi ville gøre de studerende aktivt deltagende i forhold til egen læring, og derfor var en bevægelse væk fra den primært forskningsledede forelæsningsform 
nødvendig. Vi ville øge de forskningsbaserede undervisnings- og læringsaktiviteter samt hæve kvaliteten af den forskningsstøttede undervisning, f.eks. ved at styrke de studerendes forståelse for grundbegrebers relevans for deres fagfelt, så de derved fik bedre muligheder for at indgå i gruppe- og plenumdiskussioner. Vi vurderede, at dette netop kunne muliggøres ved brug af et flipped learning undervisningsdesign.

Implementering af flipped learning undervisningsmetode kalder på mere aktive roller og relationer i undervisningsrummet (Estes et al., 2014). I tilrettelæggelsen af dette flipped learning forløb foretog vi en bevægelse væk fra mere klassiske læringsteoretiske forstålser. F.eks. hvor underviser gennem forelæsningsformen overvejende envejskommunikerer i undervisningssituationen, og de studerende tilegner sig viden gennem individuel og passiv modtagelse (Sfard, 1998). I stedet bevægede vi os ind i et sociokulturelt læringssyn. Kernen i et sociokulturelt menneske- og læringssyn er en forståelse af mennesket som eksistentielt afhængigt af social og kulturel integration. Menneskets sociale identitet og oplevelse af at betyde noget for fællesskabet formes af oplevelser og erfaringer fra samspillet med andre og integration i allerede sociokulturelle og menneskelige betydninger og praksisser. Det sociokulturelle læringssyn har fokus på samspil / kontekst frem for individ, fordi læring foregår i gensidigt konstituerende processer mellem menneske og kontekst (Bruner, 1999). Læring er derfor heller ikke et synonym for undervisning. Læring fra et sociokulturelt ståsted understreger, at viden bliver konstrueret gennem interaktion og i en kontekst (Dysthe, 2003).

Med denne bevægelse i læringssyn får de studerende roller som aktive medspillere i undervisningen, der også bærer ansvar for egen læring. Dette skaber også nye krav til undervisers rolle. Kugels (1993) klassiske femstadie model illustrerer undervisers personlige undervisningsudvikling fra fokus på sig selv (stadie 1), til emnet (stadie 2) og til de studerende (stadie 3). I de 3 stadier er de studerende passive modtagere af underviserens formidling, og underviser har rolle som 'ekspert'. I stadie 4 flyttes fokus fra undervisning til læring, og de studerende bliver aktive medspillere, og underviser făr rolle som 'træner'. I stadie 5 faciliterer underviser rammer, der muliggør, at de studerende kan tage ansvar for egen læring (Kugel, 1993). Underviser har i forelæsningsformen primært haft rolle som 'ekspert', men ved flipped learning metoden flyttes undervisers rolle i langt højere grad over mod 'træner' og 'facilitator'. I flipped learning undervisningen i videnskabsteori agerer underviser stadig 'ekspert' i pre-class aktiviteter, men i in-class får hun rolle som 'træner' og 'facilitator'. De studerendes læringsudbytte kommer derved også til at hænge sammen med både undervisers og studerendes accept af nye roller og relationer i undervisningssituationen.

Et scoping review, der inkluderede 28 studier, konkluderede, at flipped learning har potentiale til at sætte undervisere bedre i stand til at kultivere kritisk og selvstændig tænkning hos de studerende, samt skabe evne til livslang læring og derigennem forberede de studerende til deres fremtidige arbejdsliv (O'Flaherty \& Phillips, 2015). Dog peger studier på, at flipped learning bedst lykkes, når underviseren gør undervisningen personligt relevant for de studerende og gennemskuelig ved at forklare det pædagogiske formål med flipped learning for de studerende, samt tilpasser undervisningen i forhold til styrker og svagheder, når disse dukker op undervejs i forløbet (Estes et al., 2014; O'Flaherty \& Phillips, 2015; Talbert, 2014). De studerende havde ligeså i den tidligere evaluering givet udtryk for, at undervisningen ikke var personligt relevant, og det påvirkede deres deltagelse i undervisningen. Derfor lavede vi en introduktionsvideo, hvor det pædagogiske formål med flipped learning og fagets relevans for deres fagfelt blev formidlet. For at kunne tilpasse undervisningen i forhold til styrker og svagheder, når disse dukkede op undervejs i forløbet (og for at bedre opdage disse) benyttedes "one-minute papers". Det er en et-minuts evaluering distribueret sidst $\mathrm{i}$ in-class undervisningen. One-minute papers leverer øjeblikkelig og konkret feedback på både de studerendes læring samt underviserens rolle, og fremmer ligeså de studerendes indflydelse på undervisningen og deres bevidsthed om egen læring (Stead, 2005).

På denne baggrund tilrettelagde vi et flipped learning undervisningsforløb i videnskabsteori. 


\section{Undervisningsforløb}

I flipped learning undervisningsdesignet benyttede vi en forskningsorienteret tilgang til pre-class aktiviteterne som primært bestod af forelæsningsvideoerne og læsning af pensum. Underviser guidede de i studerende i en forskningsstøttet tilgang, hvor de diskuterede videnskabsteoretiske emner i grupper og plenum samt i at arbejde forskningsbaseret med videnskabsteoretiske problemstillinger, -spørgsmål og -metoder i forhold til deres audiologiske eller audiologopædiske fagfelt.

Undervisningsforløbet bestod af 8 in-class lektioner af 45 minutters varighed, fordelt på 4 dage med videnskabsteoretiske emner: "Erkendelsesteori 1", "erkendelsesteori 2", "faglige modeller, begreber og klassifikation" samt "videnskab og etik". Forud for in-class havde de studerende haft adgang til 1-2 forelæsningsvideoer om hvert emne. Disse varede cirka 10 minutter og omhandlede emnets hovedbegreber og forståelser. Endvidere havde de studerende haft adgang til en introduktionsvideo til "meningen med flipped learning" af cirka 5 minutters varighed. I denne video forklaredes de studerende, hvorfor denne undervisningsform var tilvalg, hvilke forventninger der var til de studerende, samt hvad de kunne forvente af undervisningen og underviser.

Hver in-class afsluttedes med et 'one-minute paper' med to spørgsmål (Stead, 2005). Det havde et todelt formål, hvor de studerende skulle reflektere over: 1. Hvad de havde fået med fra dagens undervisning (første spørgsmål: Hvad tager du med fra undervisningen i dag?), samt 2. hvad de gerne ville have mere viden om (andet spørgsmål: Hvad vil du gerne have uddybet?).

\section{Problemformulering}

I dette studie undersøger vi de studerendes oplevelse af undervisningsforløbets læringspotentiale, og hvorvidt de oplever dette det relevant. Undersøgelsen omhandler 2 forskningsspørgsmål:

1. På hvilken måde og i hvilken grad oplever de studerende, at flipped learning undervisningsforløbet er relevant for dem?

2. Hvilke dele af flipped learning undervisningsforløbet oplever de studerende som understøttende for deres læring?

\section{Undersøgelsesdesign}

Et mixed methods design med både kvalitative og kvantitative undersøgelsesmetoder (Green \& Thorogood, 2004) blev benyttet til at besvare problemstillingen. Undersøgelsens data er indhentet fra tre kilder: 1) antal downloads af hver forelæsningsvideo, 2) et skriftligt spørgeskema med kvantitative og kvalitative items efter endt undervisningsforløb, samt 3) et fokusgruppe-interview med 4 studerende.

Antal downloads af videoer blev indhentet for at vide, i hvor stor udstrækning de studerende benyttede forelæsningsvideoerne, lagt ud. Vi benyttede et spørgeskema med 8 kvantitative samt 3 kvalitative items, som havde til hensigt at indfange et evaluerende perspektiv fra størstedelen af de studerende. Denne datakilde skulle bibringe en bredde i forståelsen af de studerendes oplevelse af undervisningsforløbets relevans. De studerende udfyldte spørgeskemaet ved sidste in-class undervisning. Derved forventede vi, at så mange som muligt udfyldte det. Spørgeskemaet bestod af 8 kvantitative items, hvor de studerende ratede deres oplevelse af relevans med undervisningens forskellige elementer med brug af likert-skala fra 1-5, hvor 1 var "i meget lav grad” og 5 var "i meget høj grad”. De kvantitative items havde fokus på graden af de studerendes oplevelse af undervisningsforløbets relevans, og på hvilken måde de oplevede, at den understøttede deres læring. Endvidere spurgte vi ind til de studerendes forberedelse og deltagelse i undervisning, for derved at få indsigt $\mathrm{i}$, hvorvidt metoden var med til at øge graden af deres oplevede deltagelse i egen læring. Ét spørgsmål søgte at spørge ind til, hvilke dele af 
undervisningsforløbet, de studerende oplevede særligt relevant ift. at understøtte deres læring. Ved besvarelse af dette spørgsmål kunne de studerende vælge én af 6 svarmuligheder, eller de kunne tilføje deres eget svar, hvis de ikke fandt én af de seks dækkende.

Indeholdt i spørgeskemaet var tre kvalitative items, hvor de studerende med egne ord kunne udfolde deres oplevelse af relevans med undervisningsforløbet. Disse var: "Hvad oplevede du positivt ved undervisning med flipped learning?", "Hvad oplevede du negativt ved undervisning med flipped learning?", og "Har du andre kommentarer?”. Formålet med de kvalitative items var at undersøge på hvilken måde de studerende oplevede undervisningsforløbet som relevant for dem, samt hvilke dele de oplevede som understøttende for deres læring. Med henblik på at komplementere spørgeskemaundersøgelsen og få en dybere indsigt i formålet med de kvalitative items udførte vi også et fokusgruppe-interview (Halkier, 2016) med 4 studerende, der havde meldt sig frivilligt til at deltage ved sidste in-class undervisning. For at få adgang til de studerendes beskrivelser af både på hvilken måde og hvilke dele af undervisningsforløbet, de oplevede som relevant og læringsunderstøttende, benyttede vi Interpretative Phenomenological Analysis (IPA), som forskningsmetode og -design (Smith et al., 2009). IPA er en psykologisk kvalitativ metode, som benytter en hermeneutisk-fænomenologisk tilgang, der fokuserer på beskrivelse og fortolkning af datamaterialet. IPA er en oplagt tilgang, når man undersøger, hvordan personer opfatter de situationer, de står overfor, eller når man forsøger at forstå indholdet og kompleksiteten af de beskrivelser, som individer bruger til at skabe mening i forskellige situationer (Smith \& Osborn, 2003; Smith \& Osborn, 2008).

Til fokusgruppe-interviewet udarbejdede vi en moderator-guide på baggrund af forskningsspørgsmålene og ønsket om uddybelse af de studerendes besvarelser af spørgeskemaet. De betydninger og forståelser, som vi forventede ville opstå i interaktionen mellem interview-personerne, var netop den form for data, som kunne bibringe nuancerede perspektiver på problemstillingen.

\section{Informanter og setting}

Undersøgelsen indgik i et udviklingsprojekt, som en del af universitetspædagogikum på Syddansk Universitet, som førsteforfatteren i 2019 deltog i. Undervisningsforløbet er en del af førsteforfatters undervisningsforpligtigelse som ansat ved Syddansk Universitet. Førsteforfatteren har derfor selv sammensat undervisningsforløbet, udført det og foretaget undersøgelsen. Anden forfatter har været vejleder for førsteforfatter under universitetspædagogikum og derigennem bidraget til alle faser af undersøgelsen.

Faget videnskabsteori er en del af 3. semester på bacheloruddannelsen i hhv. audiologi og audiologopædi. Der er studerende fra begge uddannelser tilstede i undervisningen, som foregår på Syddansk Universitet. Normalvist deltager 35-45 studerende til in-class undervisningen, men 65 studerende tilmeldte sig eksamen i januar 2020.

Spørgeskemaet blev distribueret ved sidste undervisningsgang, og 36 studerende besvarede det, dvs. der var en svarprocent på 55\%. Af disse var 31 kvinder og 5 mænd, og gennemsnitsalderen var 22,7 år. Denne alders - og kønsfordeling vurderes som repræsentativ for de studerende i audiologi og audiologopædi.

Der var 13 studerende, som havde meldt sig frivilligt til at deltage i fokusgruppe-interview, men da de blev bedt om at tilmelde sig specifikke tidspunkter for afholdelse af interviewet, var det kun muligt at få 5 studerende til at deltage i samme tidsrum. Af disse meldte én studerende fra på dagen for interviewet. Ud af de fire interviewede studerende var to fra audiologi-uddannelsen og to fra audiologopædi-uddannelsen. De var alle fire kvinder i alderen 21-23 år. Fokusgruppe-interviewet blev afholdt i et uforstyrret mødelokale i en bygning tæt ved de studerendes studiested. Det varede 48 minutter. Førsteforfatteren, som også var underviser på undervisningsforløbet, var ligeledes moderator for fokusgruppe-interviewet. 


\section{Etik}

Etiske principper om mundtligt og skriftligt informeret samtykke, frivillighed, anonymitet og fortrolighed blev fulgt i overensstemmelse med GDPR, og undersøgelsen blev udført i henhold til dansk lovgivning om persondata. De studerende var også blevet skriftligt og mundtligt informeret om undersøgelsens formål og deres anonymitet, inden udførelse af spørgeskema-undersøgelsen og fokusgruppe-interview. Deres forbindelse til antal downloads af videoer samt udfyldelse af spørgeskema kunne ikke spores tilbage til den enkelte person. Deltagerne i fokusgruppe-interview blev informeret om, at de både under og efter interviewet havde mulighed for at trække sig fra undersøgelsen.

\section{Analyse strategi}

Vi præsenterer alle data indhentet på baggrund af de 8 kvantitative spørgsmål. 7 af disse bliver præsenteret med grupperede søjlediagrammer og et enkelt med cirkeldiagram. Med de grupperede søjlediagrammer ønsker vi på en let overskuelig måde at præsentere graden af de studerendes oplevelse af undervisningsforløbets relevans og deres deltagelse. Med cirkeldiagrammet vil vi sætte fokus på, hvilke dele af undervisningsforløbet, de studerende oplevede, understøttede deres læring.

Til analyse af de kvalitative data benyttede vi den fortolkende fænomenologiske analysestrategi, Interpretative Phenomenological Analysis (IPA) (Smith et al., 2009; Smith \& Osborn, 2003) som netop har fokus på den mening og forståelse, som mennesker beskriver deres oplevelser med. Denne analysestrategi havde til hensigt at bibringe en dybere forståelse for, på hvilken måde, de studerende oplevede, undervisningsforløbet som relevant, samt hvilke dele af det, de oplevede som understøttende for deres læring.

Besvarelser af de kvalitative spørgsmål fra spørgeskemaet samt transkription af fokusgruppe-interviewet blev tematisk analyseret med fokus på deltagernes beskrivelser af deres oplevelser med og tanker om flipped learning metoden. I transkriptionen af fokusgruppe-interviewet blev meningsindholdet vægtet; talelyde og gentagelser udgik, mens tænkepauser og følelsesudtryk indgik, således at transskriptionen fremstod med forståelse for deltagernes udsagn og meningsvægtninger.

Der er ingen enkelt og endelig måde at udføre IPA på. De fire faser i analyseprocessen præsenteret af Smith og Osborn (2003) blev anvendt som en arbejdsmodel til analysen af denne undersøgelse:

1. Kvalitative udsagn fra spørgsmålene og transskription af fokusgruppe-interview blev læst og genlæst for at blive bekendt med datasættet. Forskerne skrev kommentarer og forsøgte at sammenfatte, se forbindelser og foretage foreløbige fortolkninger.

2. Forskerne vendte tilbage til begyndelsen af hver transskription. Indledende noter blev gradvist omdannet til kortfattede sætninger relateret til projektets problemformulering. De oprindelige noter fra den første fase blev omdannet til overordnede temaer på tværs af begge kvalitative datakilder.

3. De nye temaer blev oplistet, og forbindelser mellem dem blev undersøgt for at opnå en analytisk forståelse af forbindelserne mellem de temaer, der opstod i fase to.

4. De temaer der opstod i trin tre blev givet tematiske navne, og en struktur for deltagernes tanker og meninger om projektets problemformulering opstod. Temaer uden bred dokumentation i data, eller temaer der blev vurderet af mindre relevans for problemformuleringen, blev udeladt. Forskerne prioriterede og reducerede temaerne. De identificerede temaer reflekterer derfor forskernes fortolkning, men de blev gentagne gange kontrolleret mod data for at sikre deres forankring i det empiriske materiale. 


\section{Resultater}

I nedenstående resultatafsnit præsenteres først analyser af de kvantitative data som består af downloads af forelæsningsvideoer samt besvarelserne fra spørgeskema-undersøgelsen. Derefter præsenteres den fortolkende fænomenologisk analyse af de kvalitative data med henblik at diskutere det samlede data i forhold til undersøgelsens forskningsspørgsmål.

\section{Kvantitative data}

Normalvist deltager 35-45 studerende i in-class undervisningen, men 65 antal studerende gik til eksamen. Dette tal indikerer, at der er cirka en tredjedel af de studerende, der selvstuderer faget. Hvorvidt de selvstuderende har benyttet forelæsningsvideoerne, kan vi desværre ikke indhente viden om. Der er foretaget: 78 downloads af videoen: "Introduktion til flipped learning", 120 downloads af videoen: "Erkendelsesteori 1", 90 downloads af videoen: "Erkendelsesteori 2", 105 downloads af videoen: "Faglige modeller og klassifikationer 1", 102 downloads af videoen: "Faglige modeller og klassifikationer 2" og 101 downloads af videoen: "Etik og videnskabsteori". Dette tyder på, at en stor del af de studerende har set videoerne, og flere af dem har set hver enkelt video mere end én gang.

Nedenfor præsenteres de kvantitative data fra spørgeskema-undersøgelsen. Spørgsmål var besvaret på likertskala fra 1-5, hvor 1 var "I meget lav grad” og 5 var ”i meget høj grad”. De første tre søjlediagrammer omhandler de studerendes overordnede oplevelse af deres læringsudbytte af undervisningsforløbet.

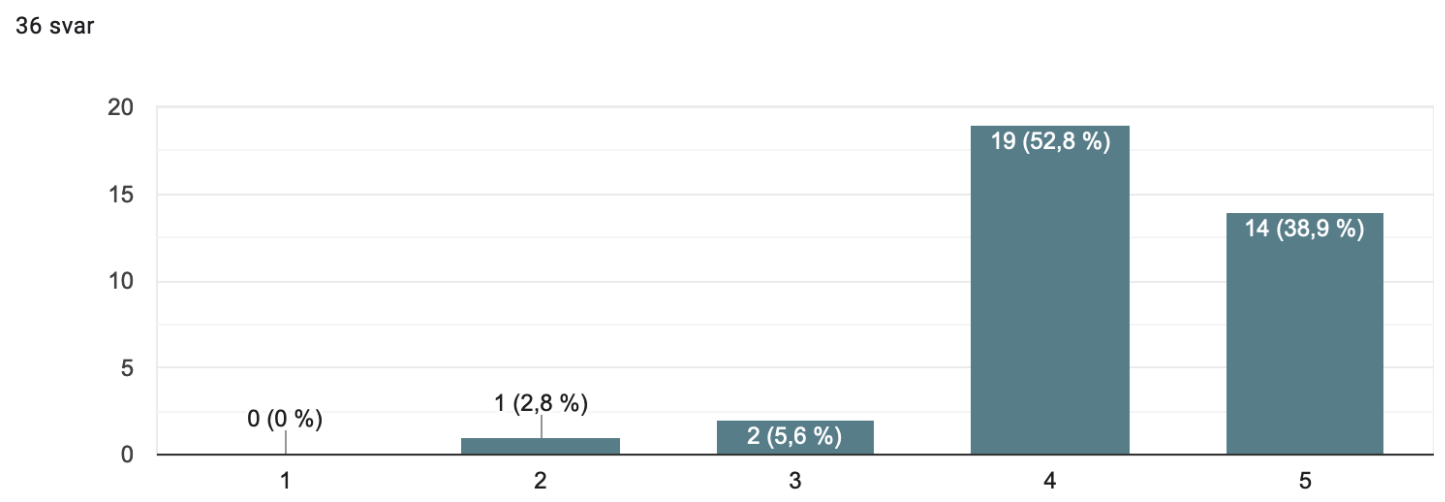

Figur 1. Spm: Hvordan oplever du, at dit overordnede læringsudbytte har været af undervisning med flipped learning?

36 svar

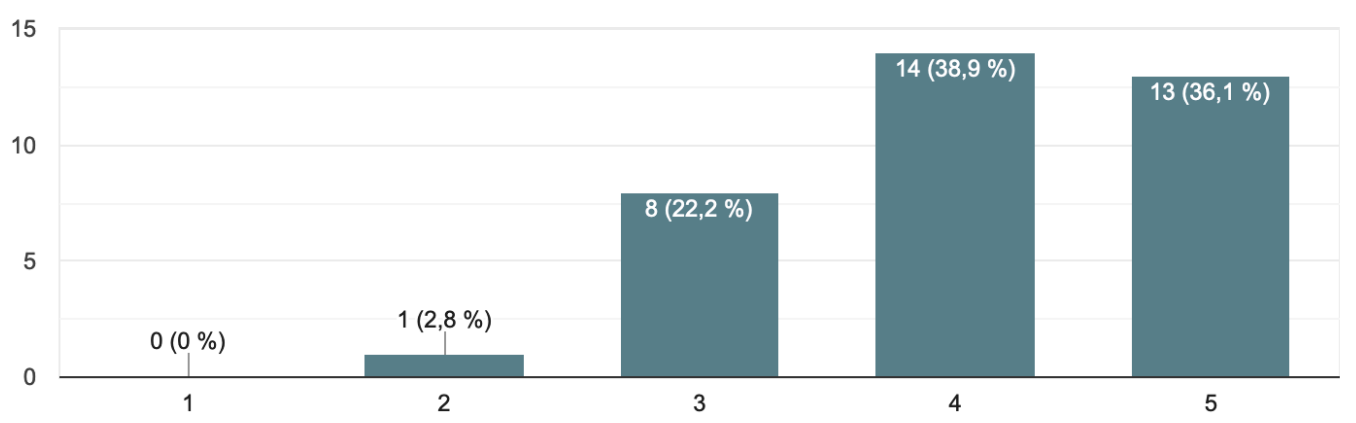

Figur 2. Spm: I hvor høj grad synes du, at du lærer mere ved flipped learning metoden fremfor almindelig forelæsning? 
36 svar

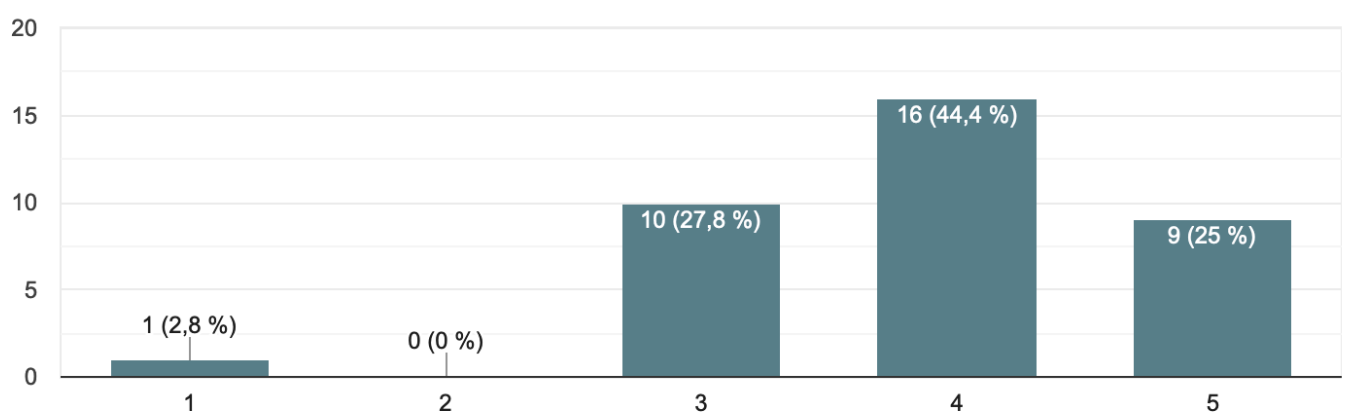

Figur 3. Spm: I hvor høj grad oplever du dig forberedt til eksamen gennem flipped learning undervisningen?

Når man kigger på de studerendes besvarelser af disse spørgsmål ovenfor, så ses det, at de studerende overvejende vurderer, at de har oplevet et højt læringsudbytte med flipped learning. De vurderer deres overordnede læringsudbytte af flipped learning (figur 1) højt, hvilket kan tyde på, at de har oplevet at undervisningsmetoden understøttede deres læring. De vurderer i lidt mindre grad, om end stadigt højt, at de har lært mere ved flipped learning metoden fremfor almindelige forelæsninger (figur 2). Dette mindre fald i vurdering er væsentligt at undersøge betydningen af, ligesom der også ses et dyk i forhold til deres vurdering af metodens eksamensforberedende funktion (figur 3). Dette spørgsmål omhandler netop en konkret spørgen ind til deres oplevelse af, hvorvidt undervisningsforløbet understøttede deres læring på en eksamensforberedende måde, og her ses det, at de vurderer dette i mindre grad.

Nedenfor præsenterer vi 2 søjlediagrammer og et cirkeldiagram, der omhandler i hvilken grad, de studerende vurderer metoden er relevant, og hvilke dele af den, de vurderer, er det.

36 svar

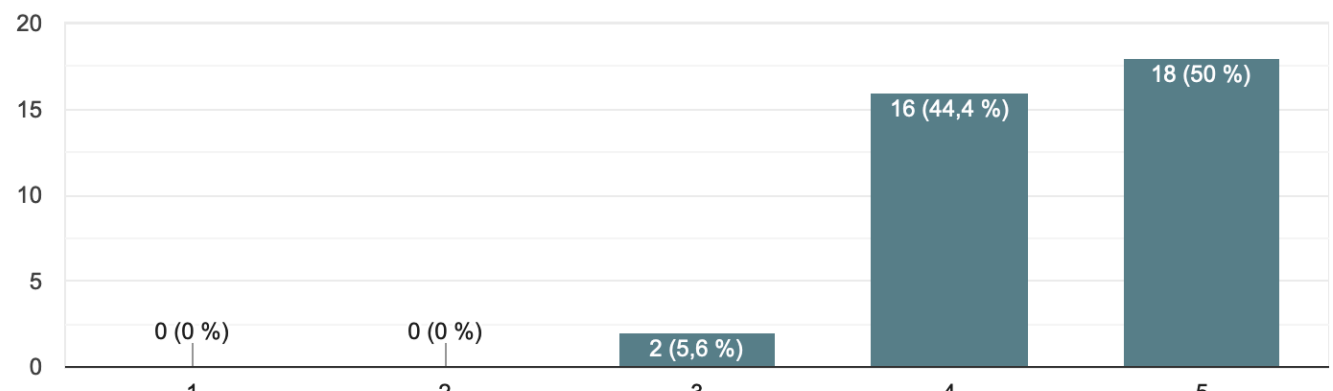

3

4

Figur 4. Spm: I hvor høj grad oplever du, at flipped learning er en relevant undervisningsform for dig? 
36 svar

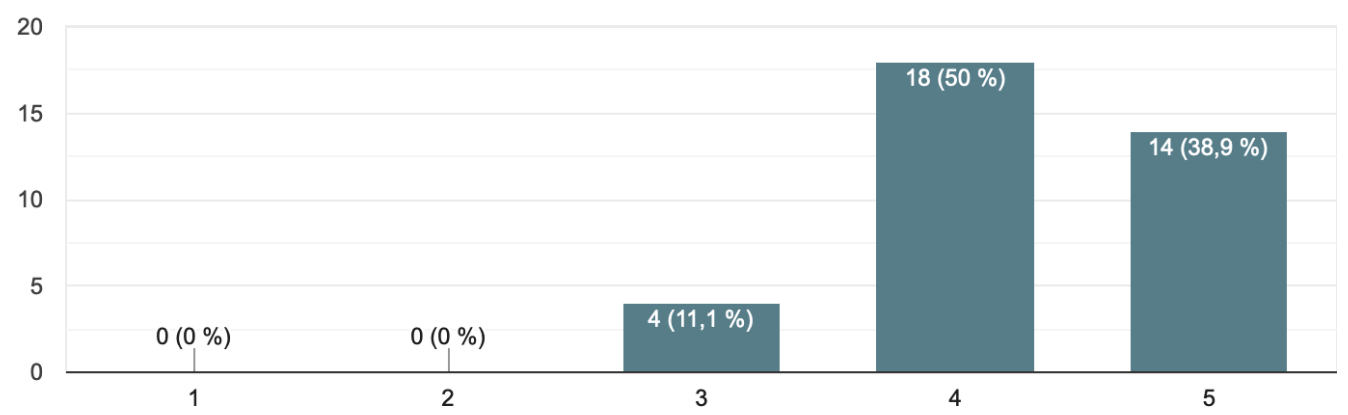

Figur 5. Spm: I hvor høj grad oplevede du, at videnskabsteori blev relevant gennem flipped learning undervisningsmetoden?

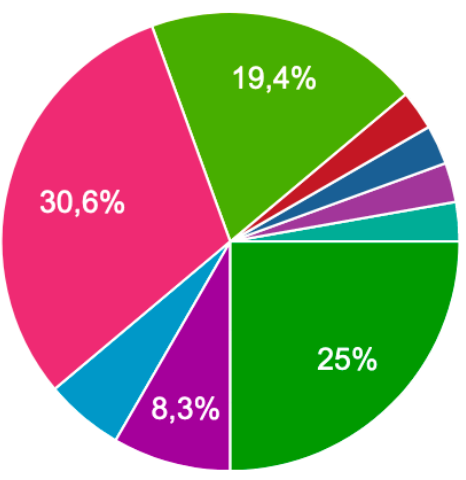

Videoforelæsningerne

Gruppediskussionerne

One minute paper

Opsamling i plenum

Dorte der talte i face-to-face undervisn...

Arbejde med eksamensopgaver

Video forelæsningerne

Gruppe diskussionerne

$1 / 2$

Figur 6. Spm: Hvilken del af undervisningen oplevede du særligt relevant?

Det fremgår af disse data, at de studerende overvejende har oplevet flipped learning undervisningsmetoden som en relevant undervisningsform (figur 4). Ligesom de også har oplevet den som en relevant undervisningsmetode for faget videnskabsteori (figur 5). Disse spørgsmål har fokus på graden af de studerendes oplevelse af undervisningsforløbets relevans, og de studerende giver udtryk for, at de har oplevet denne i høj grad. Når de studernde skal pege på, hvilke dele af undervisningen, som de tilskriver relevans, peger de primært på 3 af de 6 svarmuligheder, de kunne vælge mellem. Disse er: "Video-forelæsningerne" (30,6\% - 11 studerende), "opsamling i plenum" (25\% - 9 studerende) og "gruppediskussioner" (19,4\% - 7 studerende). Blot 3 studerende $(8,3 \%)$ peger på "underviser der taler i face-to-face undervisningen", 2 studerende $(5,6 \%)$ "arbejde med eksamensopgaver" og ingen peger på "one minute paper".

Der var 4 studerende, som havde tilføjet deres eget svar i stedet for at vælge et at de 6 valgmuligheder. Disse svar var: "Videoforelæsninger, gruppe-diskussioner, face-to-face ift. opklaring af spørgsmål og opsamling i plenum", "arbejde med eksamensopgaver, gruppe-diskussion, videoforelæsning, opsamling, face-to-face", "dem alle sammen" og "det hele giver god mening for mig. Det er dejligt at få lov til at tale sammen, så falder jeg ikke i søvn. Det er spændende diskussioner. Underviser er meget engageret og har gode eksempler. Vi er ikke så gode til at sige noget, fordi vi ikke er vant til det. One Minute Papers var ikke så vigtige for mig, fordi undervisningen var så god, at jeg havde styr på det meste”. 
Disse 4 kommentarer af mere kvalitativ karakter omhandler, at disse 4 studerende gerne vil pege på alle 6 svarmuligheder, med undtagelse af brug af one-minute paper, som de studerende generelt ikke beskrev som relevant.

I forhold til de studerendes vurdering af deres forberedelse og deltagelse, som skulle sige noget om, hvorvidt de oplevede, at undervisningsmetoden øger graden af deres deltagelse i egen læring, benyttedes to spørgsmål. De studerende vurderer, at de har forberedt sig godt til timerne (figur 7), men de vurderer deres deltagelse i in-class (figur 8) en del lavere end ved forberedelse.

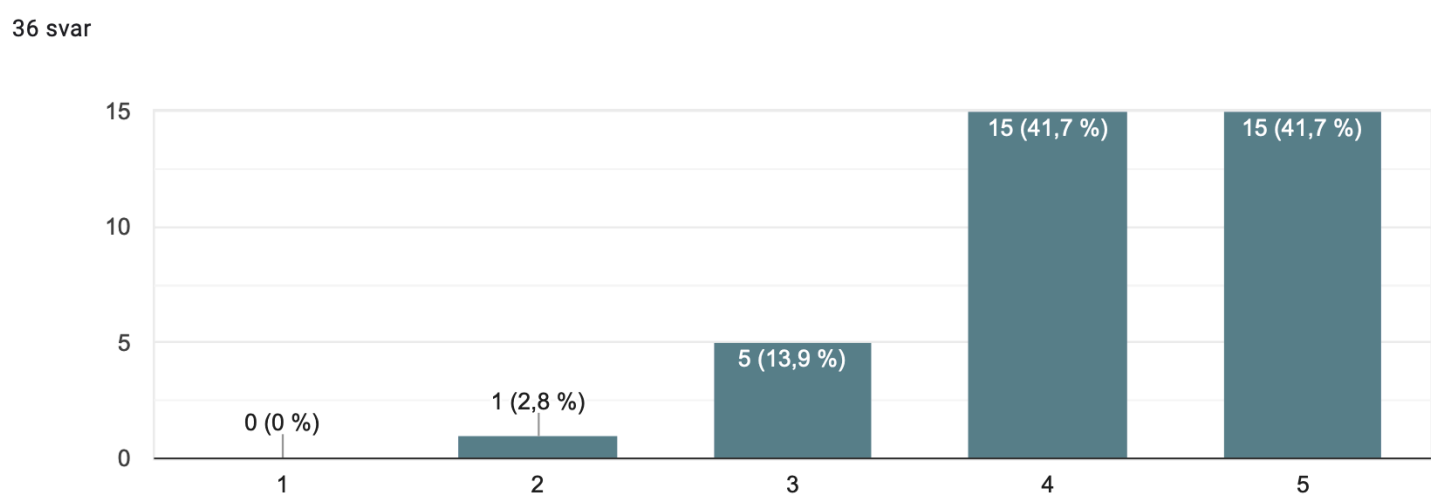

Figur 7. Spm: I hvor høj grad havde du forberedt dig inden in-class timerne (set videoer, læst pensum, etc.)?

36 svar

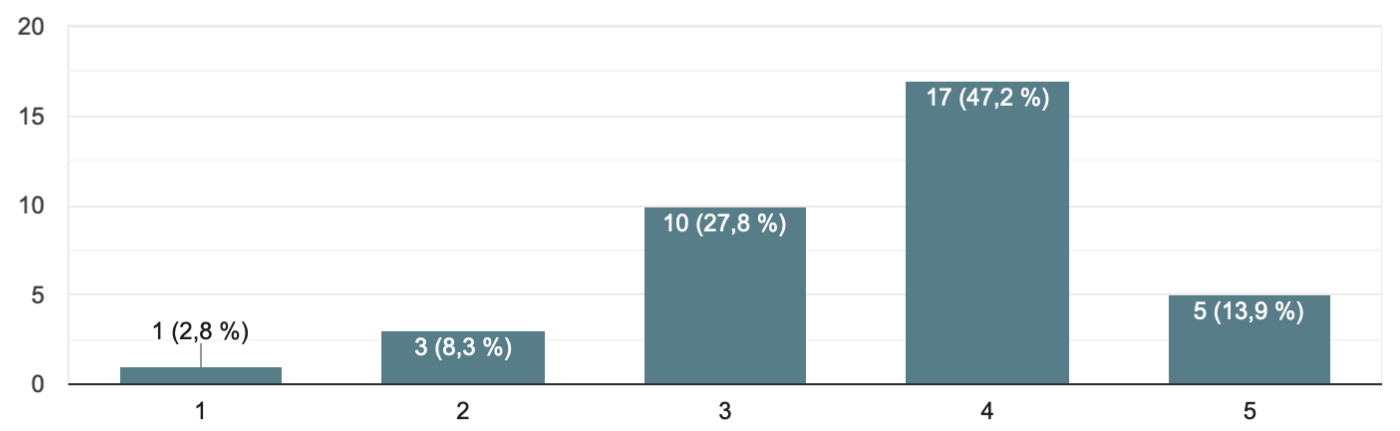

Figur 8. Spm: I hvor høj grad har du være aktivt deltagende i in-class timerne?

Overordnet peger de kvantitative dele af spørgeskemaet på, at de studerende i høj grad oplevede flipped learning undervisningsforløbet som relevant, og ligeså som understøttende for deres læring. De peger særligt på, at de oplevede metodens del-elementer: Video-forelæsninger, opsamling i plenum og gruppediskussioner, som særligt relevante. For at indhente en større viden om, de forståelser og meninger, som de studerende ligger i deres vurderinger og for at kunne besvare projektets problemformulering, så indeholdte spørgeskemaet nogle uddybende kvalitative spørgsmål. Disse svar blev komplementeret med et fokusgruppe-interview med 4 studerende. Analyse af disse kvalitative data præsenteres nedenfor.

\section{Kvalitative data}

Fire temaer blev fremanalyseret i de kvalitative data: 1. Meningsskabelse, 2. Forberedelse og deltagelse, 3. Forventninger og 4. Relationer. 


\section{Mening}

Dette tema omhandler, at de studerende gav udtryk for, at de oplevede flipped learning som en meningsfuld undervisningsmetode i forhold til det konkrete fag, videnskabsteori, som de skulle lære og havde en snarlig eksamen i. Data fra både spørgeskema og fokusgruppe-interviews viste, at de studerende generelt oplevede flipped learning metoden som relevant for videnskabsteori. For eksempel skrev en studerende:

"Det (flipped learning) har fungeret vildt godt for faget videnskabsteori"

Forståelsen af, at flipped learning var særligt velegnet til faget videnskabsteori var gennemgående i datamaterialet. En anden studerende skrev mere uddybende:

"Brugen af begreberne er specielt vigtigt i videnskabsteori, og det fik vi lov til. Man kan godt definere et begreb, men faktisk at bruge det, det lærte jeg ved flipped learning."

Denne oplevelse af relevans med flipped learning for videnskabsteori, hvor de studerende begynder at tænke og meningsskabe videnskabsteoretisk i deres hverdagsliv blev uddybet i fokusgruppe-interviewet. En studerende udtalte:

"Jeg er begyndt at tænke videnskabsteoretisk... for eksempel, når jeg hører radio om morgenen, så var der lige et interview... så tænkte jeg, det der er slet ikke validt. De udsiger meget mere, end den undersøgelse kan sige... de havde kun spurgt 60 kvinder, og det var fra alle aldre [...] Sådan har jeg ikke tænkt før, når jeg hørte nyhederne. Men det gør jeg nu."

De studerende gav udtryk for, at videnskabsteori gennem undervisningsforløbet blev relevant på en meningsfuld måde for deres fag og liv, og det oplevede de både positivt og overraskende. For eksempel udtrykte en studerende i fokusgruppe-interviewet sig således:

"Når jeg taler med de studerende på 1. semester, så siger jeg, at de kan glæde sig til det her fag. At det kan man bruge til noget... det var ikke det, som de (studerende før deres årgang) sagde til os. De sagde, at videnskabsteori er sådan lidt... (trækker ligegyldigt på skulderen)."

De studerende udtrykte, at videnskabsteori gennem flipped learning forløbet var blevet relevant på en måde, hvor de kunne bruge undervisningen i meningsfuldt i forhold til både deres liv, fag og den kommende eksamen. De tilskrev dette forskellige dele af undervisningen, ligesom de også beskrev udfordringer med undervisningsforløbet. Dette bliver uddybet under de andre temaer.

\section{Forberedelse og deltagelse}

De studerende gav udtryk for, hvordan forberedelse til og deltagelse i undervisningen var væsentlige faktorer i forhold til deres oplevede læringsudbytte. Det handler dette tema om. I besvarelsen af de kvalitative spørgsmål udtrykte de studerende sig forskelligt i forhold til pre-class forberedelsen. For eksempel skrev tre studerende:

"man turde ikke komme, hvis man var uforberedt."

"du husker ekstra meget på at forberede dig til timen."

"Lidt træls hvis nogen ikke havde forberedt sig." 
Disse tre kommentarer omhandler de studerendes pre-class forberedelse og dermed forudsætningerne for deres in-class deltagelse. En studerende beskrev, at han / hun ikke ville komme, hvis han / hun ikke var forberedt, mens den næste studerende udtrykte motivation ved at forberede sig til denne undervisningsform. Både i de kvalitative besvarelser og fokusgruppe-interviewet gav de studerende udtryk for udfordringen ved, når klassekammerater ikke havde forberedt sig, og hvordan det gjorde deltagelse svær for andre. De studerende udtrykte, hvordan de oplevede, at læringsudbyttet var udfordret af forberedelse. De beskrev særligt en oplevet nødvendighed af, at de bliver givet gode muligheder for at administrere deres forberedelsestid. For eksempel skrev en studerende:

"Generelt synes jeg, at videoerne er lagt på blackboard for sent - jeg synes ikke, der har været mulighed for selv at administrere min forberedelsestid."

I fokusgruppe-interviewet blev muligheder for at tilrettelægge egen forberedelsestid også fremhævet og uddybet som noget, de studerende mente, kunne forvente at løse nogle af udfordringer ved mangelfuld forberedelse og derved øge deres deltagelse. På samme tid udtrykte de studerende både i de kvalitative spørgsmål og fokusgruppe-interviewet en generel oplevelse af, at de deltog mere aktivt i flipped learning metodens in-class aktiviteter, end de normalvis gør i undervisning, fordi disse er fokuseret på gruppediskussioner. For eksempel skrev en studerende:

"Jeg rækker typisk ikke hånden op i timerne, fordi jeg er usikker på, at det jeg siger er forkert. Derfor syntes jeg dette (flipped learnings gruppe-diskussioner) var godt, fordi man først kunne snakke sammen i grupper, og så havde man pludselig lyst til at fortælle, fordi de andre også mente det samme, og man derfor godt kunne sige det højt."

Til trods for at de studerende i det kvantitative spørgsmål gav udtryk for, at de oplevede deres deltagelse $\mathrm{i}$ in-class lavere end deres forberedelse, så ses det i det kvalitative data, at de studerende generelt oplevede at være mere aktive i gruppe-diskussionerne, end de vurderer sig at være i den klassiske forelæsningsundervisning. Dog beskrev nogle studerende også, at de oplevede, at gruppe-diskussionerne fyldte for meget, så der ikke var nok tid til opsamling i plenum. Nedenfor er der to eksempler på dette:

"Nogle gange er der brugt for meget tid i grupperne, så underviser næsten ikke kan nå at forklare, hvad der er meningen / den rigtige forståelse / de korrekte teorier."

"Nogle gange var opsamlingen i plenum lidt for kort."

Udtalelser som disse indikerer, at de studerende har en forståelse af, underviseren som 'ekspert' der besidder de rigtige svar, og derfor oplever de opsamling i plenum væsentligt for deres læringsudbytte. Dette uddybes mere i forbindelse med tredje tema om de studerendes forventninger.

\section{Forventninger}

Dette tredje tema beskriver, hvordan de studerendes forventninger til undervisningen også former, på hvilken måde de oplevede undervisningsforløbet som relevant. De studerende udtrykte forventninger om, at underviseren er den, der har de 'rigtige' svar, og derfor tilskriver de også opsamling i plenum større værdi end gruppe-diskussioner. Det finder vi i de kvantitative data, når de studerende skulle pege på, hvilke dele af undervisningen de fandt mest relevant (figur 6), og samme tendens var ligeså i flere af de kvalitative svar i spørgeskemaet. For eksempel skrev to studerende:

"det er VIGTIGT med opsamling, ellers bliver det bare en gættetime."

"(Svar til hvad, de studerende oplevede negativt ved flipped learning) At man ikke bagefter havde sådan, sort på hvidt, hvad svaret var. Altså at du (underviseren) ikke havde et løsningsforslag i dine slides." 
Der var også en studerende, der detaljeret beskrev, hvordan han / hun oplevede flipped learning positivt. I denne beskrivelse ser vi, hvordan denne studerende havde tilpasset sine forventninger til denne undervisningsform, og ligeså så sig selv som skabende af egen læring igennem gruppe-diskussionerne:

\footnotetext{
"Jeg kunne godt lide, at man fik en forsmag på undervisningen derhjemme i form af videoerne, og på den måde sortere lidt i den information, jeg skulle læse. Det blev nemmere at læse teksterne, fordi jeg kunne gå ud fra videoerne. Derudover synes jeg, at jeg har fået en bedre forståelse af begreberne og jeg har lært at diskutere dem og bruge dem i en konkret kontekst, som jeg ikke ville have gjort hvis jeg bare havde siddet derhjemme. Det har været rart at opleve aktiv læring igen, som der ellers ikke er så meget af."
}

I fokusgruppe-interviewet blev de studerendes forventninger til undervisningen diskuteret. De fire deltagere mente dog alle, at den vigtigste læring opstod i gruppe-diskussionerne, hvilket ikke nødvendigvis helt afspejler den samlede gruppe studerendes forventninger til undervisningen. Tre studerende i fokusgruppen mente, at de lærte meget mere med flipped learning metoden, mens én mente, at hun lærte lige meget ved flipped learning og klassisk forelæsningsundervisning. De gav dog alle fire udtryk for, at det var væsentligt, at de fik en klar indføring i det pædagogiske formål med flipped learning og forventninger til dem som studerende, hvis de skulle få et godt udbytte af undervisningen. Det mente de, at de havde fået i dette forløb. For eksempel sagde én af dem:

"Du (underviser) fik virkelig forklaret, helt i starten, hvad videnskabsteori kan bruges til... og også det du sagde med, at du selv ikke havde forstået meningen med det... det var sådan lidt: Det er faktisk vigtigt det her. Og så bliver man jo motiveret [...] Videoen var også meget tydelig med, hvorfor og hvordan... det var godt, synes jeg... "

Den studerende beskriver her en situation i første in-class lektion, hvor underviser fortalte om, at hun selv som bachelor studerende (i sin tid) havde bestået videnskabsteori, dog uden at forstå meningen med faget. Det var først senere i hendes uddannelse, at hun forstod faget og lærte at arbejde videnskabsteoretisk. Samtidigt beskrev hun, at hun oplevede det som et problem, fordi videnskabsteori som fag er grundlæggende for alle akademiske uddannelser. Deling af denne personlige erfaring om relevansen af videnskabsteori kommenterede de fire studerende en del på i fokusgruppe-interviewet. Det blev i interviewet tydeligt, at underviserens måde at relatere til de studerende også er en afgørende for, hvorvidt de oplever undervisningsforløbet som relevant. Sidste tema omhandler dette.

\section{Relationer}

Det sidste tema omhandler relationer som en væsentlig del af, hvorvidt de studerende oplevede flipped learning som en relevant undervisningsmetode. Dette tema opstod i det kvalitative data, hvor de studerende skrev og talte påfaldende meget om relationer. Dette fokus var ikke med i udgangspunktet for undersøgelsen, og af samme grund heller ikke en del af forskningsspørgsmålene eller fokus i spørgeskemaet, men temaets omfang blev tydeligt i analysen af data. De studerende udtrykte både vigtigheden af relationer til hinanden samt til underviser, for at de deltog aktivt i undervisningen og oplevede et godt læringsudbytte. I besvarelserne af de kvalitative spørgsmål kunne der udledes vigtigheden af de forskellige relationer; til medstuderende og til underviser, og ligeledes hvordan disse relationer ledte til en form for 'relationelt læringsrum'.

Adskillige af de studerende beskrev, hvordan relationerne til deres medstuderende i grupperne i in-class var vigtige for deres oplevelse af læring. Nogle studerende skrev:

"Dejligt at vi havde god tid til at diskutere emnerne i grupper."

"(Det var positivt) At man havde mulighed for at diskutere tingene med andre, så man også fik andres syn på tingene." 
"Det er nemmere at koncentrere sig, når man får lov at tale lidt sammen. Emnerne bliver mere spændende."

De gav ligeledes udtryk for, at underviseren, og relationen og interaktionen med hende var en væsentlig del af deres oplevelse af undervisningsforløbet. For eksempel blev der skrevet:

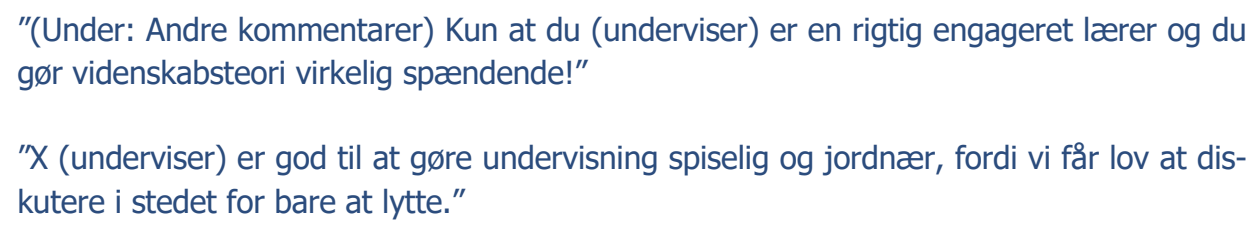

Nogle af de studerende beskrev en mere overordnet oplevelse af et 'relationelt læringsrum', da de svarede på det kvalitative spørgsmål, om hvad der var positivt ved flipped learning undervisningsforløbet. De skrev:

\author{
"Diskussionerne og nærværet." \\ "Man er mere en del af undervisningen."
}

Denne oplevelse af et positivt nærvær i læringsrummet, og den enkelte studerendes oplevelse af at være en del af undervisningen, blev søgt uddybet i fokusgruppe-interviewet. De fire studerende beskrev en oplevelse af, at det var trygt at være studerende, både når de forberedte sig derhjemme, og når de deltog i in-class aktiviteterne. En af dem forklarede for eksempel:

\begin{abstract}
Først troede jeg, at du (underviseren) ville være rigtig skrap, hvis vi ikke havde forberedt os... men sådan var det ikke... Det var trygt at komme til time. Det var også spændende [...] jeg sagde også mere i plenum, end jeg plejer, fordi jeg først have diskuteret det i den lille gruppe, hvor man ligesom var tryg... Du (underviser) er også god til at forklare ting, som man ikke forstår [...] Jeg tør godt spørge..."
\end{abstract}

Den studerende beskriver her et relationelt samspil både de studerende i mellem samt mellem de studerende og underviser. Hun fremhæver tryghed i disse relationer som væsentligt for hendes deltagelse og oplevelse af læringsudbytte.

\title{
Diskussion
}

Resultaterne fra både den kvantitative og kvalitative del af undersøgelsen peger på, at de studerende generelt og i høj grad oplever flipped learning undervisningsforløbet i videnskabsteori som relevant for dem og understøttende for deres læring. De vurderer deres overordnede læringsudbytte (figur 1) af flipped learning metoden højt. Dog sås der et mindre fald i de studerendes vurdering af flipped learning metodens læringspotentiale i forhold til almindelige forelæsninger (figur 2), samt et fald i deres vurdering af metodens eksamensforberedende funktion (figur 3). Det kan pege på, at til trods for en høj grad af oplevet læringsudbytte, så er det ikke alene flipped learning metodens læringsaktiviteter, som de studerende oplever understøtter deres læring. Modsat ser vi dog, at de studerende i høj grad både vurderer flipped learning som en relevant undervisningsmetode (figur 4), og at faget videnskabsteori blev relevant gennem flipped learning metoden (figur 5). Vi var derfor interesserede i at forstå, på hvilken måde de oplevede denne relevans, og hvilke dele af undervisningen de oplevede understøttende for læring.

Pre-class forberedelsen bestod af læsning af pensum og se forelæsningsvideoer. De studerende har downloadet forelæsningsvideoerne i høj grad, og det ser ud til at skabe nogle bedre betingelser for de studerendes læring at lave forelæsningerne som korte og koncise pre-class forberedelsesvideoer. Det var 
hensigten, at de studerende gennem pre-class forberedelsen nåede det mest basale tænkningsniveau, og de derved bedre kunne deltage i højere ordenstænkning i in-class aktiviteterne (jf Blooms taksonomi), (Estes et al., 2014). Vi fandt dog, at til trods for, at de studerende vurderer deres forberedelse højt (figur 7), vurderer de deres deltagelse i in-class aktiviteterne markant lavere (figur 8). Dette kan indikere, at det forudgående pre-class arbejde og den interaktive undervisningsform i in-class ikke nødvendigvist har fremmet de studerendes oplevelse af ejerskab for egen læring, som andre studier af flipped learning ellers peger på (Hockings et al., 2008; Lage et al., 2000; O'Flaherty \& Phillips, 2015).

30,6\% af de studerende peger på "videoforelæsningerne" og 25\% på "opsamling i plenum" som en særlig relevant del af undervisningen (figur 6). Dette kan også indikere, at en stor del af de studerendes forventninger til undervisningen er kendetegnet ved et klassisk læringssyn, hvor underviseren er 'ekspert', og de er passive modtagere af undervisning. Temaerne "forberedelse og deltagelse" samt "forventninger" peger også på dette, men samtidigt fandt vi, at nogle studerende (f.eks. de fire i fokusgruppe interviewet) påtog sig rollen som aktiv medskaber af egen læring. Vi fandt i de kvalitative data, at når de studerende forstod meningen med undervisningen og oplevede støttende relationer med hinanden og underviser, blev de aktive deltagere i egen læring. Endvidere gav de studerende udtryk for, at det ville øge deres forberedelse og deltagelse, hvis de blev givet bedre muligheder for at administrere deres pre-class forberedelse, hvilket ligeså peger på aktiv og selvstændig deltagelse i egen læring.

Flipped learning har potentiale til at sætte undervisere i stand til at skabe kritisk og selvstændig tænkning hos de studerende (O'Flaherty \& Phillips, 2015), men denne undersøgelse peger på, hvorvidt det lykkes at gøre de studerende til aktive medskabere af egen læring også hænger sammen med deres accept af nye roller og relationer i undervisningsrummet, som opstod med implementeringen af flipped learning metoden (Estes et al., 2014). Flipped learning lykkes, når underviseren gør undervisningen personligt relevant og gennemskuelig ved at forklare det pædagogiske formål med flipped learning for de studerende (Estes et al., 2014; O'Flaherty \& Phillips, 2015; Talbert, 2014). Det fandt vi også gennem temaerne "mening" og "relationer", hvor de studerende havde brug for at forstå meningen med flipped learning metoden samt gennem den relationelle interaktion acceptere de nye roller og relationer, hvorefter de blev aktive medskabere af egen læring. Det ser ud som om, de studerende oplever flipped learning undervisningsforløbet relevant, når det er meningsfuldt for dem og relationelt forankret. Dette studie peger på, at "mening" og "relationer" i læringskonteksten er to aspekter af undervisningsforløbet, som de studerende særligt oplever understøttende for deres læring.

Med implementeringen af flipped learning undervisningsmetoden forstår vi primært læring som en proces, der konstrueres i interaktionerne i den konkrete in-class kontekst (Dysthe, 2003), og hvor underviser primært har rolle som 'træner' og 'facilitator' og i mindre grad som 'ekspert' (Kugel, 1993). I dette studie gav de studerende udtryk for, at trygge relationer i undervisningskonteksten understøttede deres læring. Vi har betegnet dette "det relationelle læringsrum". Det handler om tryghed i forhold til medstuderende, underviser og at bidrage i undervisningssituationen. Det relationelle læringsrum var centralt for den måde, de studerende oplevede, at flipped learning undervisningsforløbet i videnskabsteori var relevant, og hvorvidt de blev aktive medskabere af egen læring. Når det relationelle læringsrum 'åbnede sig' for de studerende, skete der en aktiv konstruktion af viden. Læringen foregik netop i de relationelle processer mellem de studerende og læringskonteksten (Bruner, 1999), en kontekst som underviser var 'facilitator' for. De studerende pegede særligt på, at deres relationer til hinanden og til underviser hang sammen med oplevelse af undervisningen som meningsfuld. De beskrev for eksempel en situation, hvor underviser formidlede mening med faget gennem relationen til de studerende. Denne situation åbnede på en særlig måde det relationelle læringsrum.

\section{Undersøgelsens begrænsninger}

Denne undersøgelse er blevet til som en del af førsteforfatterens universitetspædagogikum, og det betyder, at hun har haft mange roller i undersøgelsen: Tilrettelægger af undervisning og undersøgelse, 
underviser, lavet spørgeskemaet samt været moderator for fokusgruppeinterviewet. Hun har undersøgt sin egen praksis. Dette kan have påvirket data. For eksempel kan de fire studerende i fokusgruppe-interviewet have udtrykt sig mere positivt, end de ville have gjort, hvis en neutral person havde været moderator. På den anden side kan de fire studerende også have sagt mere til førsteforfatteren, end de ville have gjort til en neutral moderator, fordi de har etableret en tryg relation med hende. Førsteforfatters store ejerskab for undersøgelsen kan også have vanskeliggjort klarhed i forhold til formidling af alle faser, da der kunne opstå en indforståethed. Dette er forsøgt afhjulpet ved, at førsteforfatter løbende har modtaget sparring i alle undersøgelsens faser af anden forfatter samt to eksterne vejledere fra universitetspædagogikumforløbet.

Endvidere er fire personer i en fokusgruppe få, ligesom disse fire alle var kvinder i samme aldersspænd. Det var dog overvejende kvinder i samme aldersgruppe der er tilmeldt faget, men deltagelse af flere personer i interviewet eller mere end et fokusgruppe-interviews kunne have øget undersøgelsens validitet ved at bidrage med flere og andre perspektiver på undersøgelsens fænomen. Vi har ligeså i studiet ikke sondret mellem forskellige former for pre-class forberedelse f.eks. læsning af pensum litteratur og set videoforelæsninger. Det ville være relevant at undersøge, hvordan forskellige pre-class aktiviteter påvirker de studerendes læring, og dette kunne have nuanceret studiets resultater yderligere.

Der blev benyttet et fortolkende fænomenologisk forskningsdesign og analysemetode, som der ligeledes er søgt redegjort for i undersøgelsen. Denne tilgang fokuserede på den mening og forståelse, som de studerende tillægger undervisningen, som netop var undersøgelsens fænomen. En anden analysemetode kunne have bibragt andre perspektiver og vægtninger. For eksempel kunne en mere konstruktivistisk metode have set på interaktioner mellem studerende, underviser, materiale, i gruppe-diskussioner, etc., som ligeså ville kunne frembringe relevant viden. I analysen prioriterede og reducerede forfatterne ligeså temaerne. Derfor reflekterer de identificerede temaer deres fortolkning, hvor andre forskere måske ville have set noget andet i materialet. Dog forsøgte de hele tiden at vende tilbage til de studerendes udsagn og fremhæve disse, for at sikre at fortolkningerne var forankret i deres udsagn og forståelser.

I denne undersøgelse anvendte vi et mindre mixed methods design med en overvejende kvalitativ metodologi, som har til hensigt at undersøge betydninger og forståelser af det undersøgte fænomen (Kvale \& Brinkmann, 2009). Målet med kvalitativ forskning er at fremsætte en troværdig analyse og generere hypoteser fremfor at fremskaffe generaliserbare resultater (Bryman, 2001). Denne undersøgelse peger på nogle interessante pointer, når man vil undersøge studerendes læringsudbytte af flipped learning undervisningsmetoden, men det er et lille studie med begrænset udsigelseskraft. Det er nødvendigt med yderligere undersøgelser og ligeså større studier med kvantitative designs for at kunne drage mere generelle konklusioner.

\section{Konklusion}

Formålet med dette studie var at undersøge de studerende oplevelse af et flipped learning undervisningsforløb i videnskabsteori. Et mindre mixed methods design med kvalitative og kvantitative undersøgelsesmetoder (Green \& Thorogood, 2004) blev benyttet for at opnå dette. Vi søgte, med undersøgelsen at besvare to forskningsspørgsmål: 1) På hvilken måde og i hvilken grad oplever de studerende, at flipped learning undervisningsforløbet er relevant for dem? 2) Hvilke dele af undervisningsforløbet, oplever de studerende, er understøttende for deres læring?

Ifølge analyse af data fra nærværende studie kan der konkluderes, at de studerende i høj grad oplevede flipped learning undervisningsforløbet som relevant og understøttende af deres læring. Måden hvorpå de oplevede dette, hænger også sammen med bevægelsen over mod et sociokulturelt læringssyn og øgning af forskningsbaserede og -støttede undervisningsaktiviteter, som implementeringen af flipped learning faciliterede. Studiet peger særligt på vigtigheden af formidling af meningsfuldhed med faget, for at de studerende oplever undervisningen som relevant og derved bliver aktive medskabere af egen læring. 
Denne mening blev formidlet i relationer med underviser og medstuderende, og det havde potentiale til at åbne det relationelle læringsrum. Når det relationelle læringsrum 'åbnede sig' for de studerende, skete der en aktiv konstruktion af viden.

\section{Referencer}

Barkley, E. (2010). Student engagement techniques. A handbook for college faculty. Jossey-Bass.

Bruner, J. S. (1999). Uddannelseskulturen (1. udgave, 5. oplag ed.). Hans Reitzel.

Bryman, A. (2001). Social research methods. Oxford University Press.

Bryson, C., \& Hand, L. (2007, 2007/11/o1). The role of engagement in inspiring teaching and learning.

Innovations in Education and Teaching International, 44(4), 349-362.

https://doi.org/10.1080/14703290701602748

Dohn, N. B., \& Dolin, J. (2015). Forskningbaseret undervisning. In L. Rienecker, P. S. Jørgensen, J. Dolin, \& G. H. Ingerslev (Eds.), Universitetspædagogik (3 ed.). Samfundslitteratur.

Dysthe, O. (2003). Dialog, sampil og læring. Klim.

Estes, M. D., Ingram, R., \& Liu, J. C. (2014). A review of flipped classroom research, practice, and technologies. International HETL Review, 4(7), 1-8.

Green, J., \& Thorogood, N. (2004). Qualitative Methods For Health Research. . SAGE Publications Ltd.

Halkier, B. (2016). Fokusgrupper (3. ed.). Samfundslitteratur.

Healey, M. (2005, 2005/07/01). Linking Research and Teaching to Benefit Student Learning. Journal of Geography in Higher Education, 29(2), 183-201. https://doi.org/10.1080/03098260500130387

Healey, M., Jordan, F., Pell, B., \& Short, C. (2010, 2010/05/01). The research-teaching nexus: a case study of students' awareness, experiences and perceptions of research. Innovations in Education and Teaching International, 47(2), 235-246. https://doi.org/10.1080/14703291003718968

Hockings, C., Cooke, S., Yamashita, H., McGinty, S., \& Bowl, M. (2008, 06/o1). Switched off? A study of disengagement among computing students at two universities. Research Papers in Education, 23, 191-201. https://doi.org/10.1080/02671520802048729

Krathwohl, D. R. (2002, 2002/11/o1). A Revision of Bloom's Taxonomy: An Overview. Theory Into Practice, 41(4), 212-218. https://doi.org/10.1207/s15430421tip4104 2

Kugel, P. (1993, 1993/01/01). How professors develop as teachers. Studies in Higher Education, 18(3), 315-328. https://doi.org/10.1080/03075079312331382241

Kvale, S., \& Brinkmann, S. (2009). InterView: Introduktion til et håndværk [Interview: Introduction to a craftmanship] [InterViews] (2 ed.). Hans Reizels Forlag.

Lage, M., Platt, G., \& Treglia, M. (2000, 12/01). Inverting the Classroom: A Gateway to Creating an Inclusive Learning Environment. Journal of Economic Education, 31, 30-43. https://doi.org/10.1080/00220480009596759

Mason, G. S., Shuman, T. R., \& Cook, K. E. (2013). Comparing the Effectiveness of an Inverted Classroom to a Traditional Classroom in an Upper-Division Engineering Course. IEEE Transactions on Education, 56(4), 430-435. https://doi.org/10.1109/TE.2013.2249066

O'Flaherty, J., \& Phillips, C. (2015). The use of flipped classrooms in higher education: A scoping review. The internet and higher education, 25, 85-95.

Obwegeser, N., \& Papadopoulos, P. (2016, 01/o1). Integrating research and teaching in the is classroom: Benefits for teachers and students. Journal of Information Systems Education, 27, 249-258.

Pierce, R., \& Fox, J. (2012). Vodcasts and active-learning exercises in a "flipped classroom" model of a renal pharmacotherapy module. American journal of pharmaceutical education, 76(10), 196-196. https://doi.org/10.5688/ajpe 7610196

Sfard, A. (1998, 03/o1). On Two Metaphors for Learning and the Danger of Choosing Just One. Educational researcher, 27, 4. https://doi.org/10.2307/1176193

Smith, J. A., Flowers, P., \& Larkin, M. (2009). Interpretative Phenomenological Analysis. Theory, Method and Research. SAGE Publications Ltd.

Smith, J. A., \& Osborn, M. (2003). Interpretative phenomenological analysis. In J. A. Smith (Ed.), Qualitative psychology: A practical guide to research methods (pp. 51-80). Sage.

Smith, J. A., \& Osborn, M. (2008). Interpretation phenomenological analysis. In J. A. Smith (Ed.), Qualitative psychology: A Practical guide to reseach methods (pp. 51-88). SAGE Publications Ltd.

Stead, D. R. (2005). A review of the one-minute paper. Active learning in higher education, 6(2), 118-131.

Talbert, R. (2014). Flipped learning skepticism: Is flipped learning just self-teaching? 
Wilson, S. G. (2013). The flipped class: A method to address the challenges of an undergraduate statistics course. Teaching of Psychology, 40(3), 193-199. https://doi.org/10.1177/0098628313487461 